\title{
Addition of monomeric and polymeric organic substrates alleviates viral lytic pressure on bacterial communities in coastal seawaters
}

\author{
Chiaki Motegi ${ }^{1,2,3, *}$, Toshi Nagata ${ }^{1,2}$ \\ ${ }^{1}$ Ocean Research Institute, The University of Tokyo, 1-15-1 Minamidai, Nakano-ku, Tokyo 164-8639, Japan \\ ${ }^{2}$ Center for Ecological Research, Kyoto University, 2-509-3 Hirano, Otsu, Shiga 520-2113, Japan \\ ${ }^{3}$ Present address: Université Pierre et Marie Curie-Paris 6 and CNRS, Laboratoire d'Océanographie de Villefranche, \\ 06234 Villefranche-sur-Mer, Cedex, France
}

\begin{abstract}
We examined the effect of growth conditions on the fraction of bacterial production lysed by viruses $\left(\mathrm{F}_{\text {lysed }}\right)$. Time-course changes in bacterial and viral variables were determined in coastal seawater cultures with and without the addition of monomeric (glucose or amino acids) or polymeric (protein) substrates. Substrate-induced enhancement of bacterial production was much more pronounced than that of viral production during the incubation period of 60 to $90 \mathrm{~h}$. Estimates of $\mathrm{F}_{\text {lysed }}$ were highest in non-addition controls (range $=0.3$ to 1.0), followed by the monomer addition treatment (0.1 to 0.2$)$, and lowest in the protein addition treatment (0.04 to 0.1$)$. These data are consistent with the proposition that bacterial communities grown under substrate-rich conditions are less subject to viral attacks. Low $\mathrm{F}_{\text {lysed }}$ values in the protein addition treatment were associated with high activities of leucine aminopeptidase, indicating a role of extracellular proteases in alleviating viral lytic pressure. Our data support the notion that supplies of dissolved organic matter affect the magnitude of bacteria-virus couplings in marine environments.
\end{abstract}

KEY WORDS: Virus-bacteria interactions - Lytic viral production - Dissolved organic matter • Marine environments

Resale or republication not permitted without written consent of the publisher

\section{INTRODUCTION}

Lytic viral production associated with destruction of host bacterial cells accounts for a significant, albeit highly variable (10 to $50 \%$ ), fraction of bacterial mortality in marine environments (Weinbauer 2004, Breitbart et al. 2008). Factors that may affect viral production and the extent of viral-induced bacterial mortality include the activity of host cells (Middelboe 2000). This proposition is consistent with the observation that viral production increases with increasing bacterial production or growth in response to the addition of nutrients and organic substrate (Tuomi et al. 1995, Williamson \& Paul 2004, Motegi \& Nagata 2007).

Other studies, however, have suggested that bacteria grown under nutrient-replete conditions are less vulnerable to viral attacks (Thingstad et al. 2005), because bacteria can pay 'costs' (e.g. reduction in number or modification of receptors, development of restriction enzyme-modification system; Forde \& Fitzgerald 1999, Weinbauer 2004) to reduce viralinduced mortality when resource competition is less severe. In addition, there is experimental evidence of viral loss rates increasing with increasing bacterial production from a study on nutrient enriched seawater cultures (Motegi \& Nagata 2007); one possible explanation proposed was the destruction of viral capsids by extracellular proteases released by rapidly growing bacteria (e.g. Ward et al. 1986, Noble \& Fuhrman 1997). Few studies have systematically examined the magnitude of the enhancement of bacterial and viral production in response to the addition of organic sub- 
strates, hampering coherent examination of how supplies of dissolved organic matter (DOM) affect bacteria-virus interactions in marine environments.

To better understand controls of bacteria- virus interactions in marine systems, we examined responses of bacterial and viral production to the addition of organic substrates to coastal seawater cultures. Monomeric (glucose or amino acids) and polymeric (protein) substrates were used as model substrates to investigate if patterns in responses of the bacteria-virus system differ depending on the type of substrate added.

\section{MATERIALS AND METHODS}

Sample collection and experimental setup. Experiments were conducted between 15 and 17 May 2006 (hereafter denoted as EXP06), 16 and 18 May 2007 (EXP07) and 23 and 26 May 2008 (EXP08) using seawater samples collected in the Otsuchi Bay $\left(39^{\circ} 20^{\prime} \mathrm{N}\right.$, $141^{\circ} 57^{\prime} \mathrm{E}$ ), a meso- to eutrophic embayment (Fukuda et al. 2007) located on the western North Pacific coast, Japan. A clean bucket was used to collect surface water samples from the pier of the International Coastal Research Center (Ocean Research Institute, The University of Tokyo). Water samples were transferred to $20 \mathrm{l}$ polycarbonate tanks and brought back to the laboratory. Twenty liters of water were filtered through $0.8 \mu \mathrm{m}$ pore-size filters (Isopore ATTP, diameter $142 \mathrm{~mm}$, Millipore) by applying positive pressure ( $<67 \mathrm{~cm} \mathrm{Hg}$ ) using a filtration system consisting of a stainless steel filter holder (YY3014236, Millipore), a positive pressure tank (XX6700P20, Millipore) and an air pressure pump in EXP06 and EXP07 (water samples were gravity-filtered in EXP08 without the use of the pressure tank). The use of stainless steel tools for filtration might have resulted in trace metal contamination, which is known to affect microbial activities, especially in oligotrophic waters. However, in our experiments, using productive coastal waters of the Otsuchi Bay, we assumed that these effects were minimal. The filtrates were contained in polycarbonate bottles (1 or 21 capacity, Nalgene) to prepare 3 treatments, i.e. non-addition control, monomer addition treatment and protein addition treatment. Triplicate bottles were prepared for each treatment. The monomer addition treatment consisted of water samples amended with glucose (final concentration $106 \mu \mathrm{M}$; EXP06 and EXP07) or amino acids (a mixture of 20 protein amino acids [Sigma] with a composition close to that of bovine serum albumin [BSA], final concentration $1.5 \mathrm{mg} \mathrm{l}^{-1}$; EXP08). The protein addition treatment consisted of water samples amended with BSA (final concentration $1.0 \mathrm{mg} \mathrm{l}^{-1}$ [EXP06 and EXP07] or $1.5 \mathrm{mg} \mathrm{l}^{-1}$ [EXP08]). For each treatment, $\mathrm{P}\left(\mathrm{NaH}_{2} \mathrm{PO}_{4}\right.$, final concentration
$1 \mu \mathrm{M})$ and $\mathrm{N}\left(\mathrm{NH}_{4} \mathrm{Cl}\right.$, final concentration $\left.16 \mu \mathrm{M}\right)$ were added, except that only $\mathrm{P}$ was added in EXP08. The bottles were incubated for 54 to $91 \mathrm{~h}$ at in situ temperature in the dark. For determination of microbial variables (see below), subsamples were taken from incubation bottles at 3 to $26 \mathrm{~h}$ intervals. The bucket, tanks and bottles used for the experiments were rinsed before use with $10 \%$ hydrochloric acid followed by vigorous rinsing with Milli-Q water. During sample collection and handling, gloves were worn and care was taken to minimize organic contamination.

Bacterial production. Bacterial production rate was determined from the incorporation rate of ${ }^{3} \mathrm{H}$-thymidine $\left({ }^{3} \mathrm{H}\right.$-TdR) using a centrifuge method (Kirchman 2001). Triplicate subsamples $(1.5 \mathrm{ml}$, contained in screw-capped centrifuge tubes, SSI) and 1 trichloroacetic acid (TCA)-killed control were spiked with [methyl- ${ }^{3} \mathrm{H}$ ] TdR (78 to $87 \mathrm{Ci} \mathrm{mmol}^{-1}$, GE Healthcare, TRK686, final concentration $10 \mathrm{nM}$ ) and incubated for 15 min at in situ temperature in the dark. Extraction by precipitations with $5 \%$ cold TCA was followed by cold ethanol rinsing using a temperature-controlled desktop centrifuge $\left(18000 \times g\right.$ at $4^{\circ} \mathrm{C}$ for $10 \mathrm{~min}$ for each run; Eppendorf, 5417R). The extracts were then completely dried and mixed with scintillation cocktail $(1 \mathrm{ml}$, Ultima Gold, Packard Instruments) for the radioassay using a Perkin-Elmer Tri-Carb 1500TR scintillation counter with corrections for quenching. The coefficient of variation $(\mathrm{CV})$ of the triplicate measurements ranged from 0 to $39 \%$. The ${ }^{3} \mathrm{H}$-TdR incorporation rates were converted to cell production by the conversion factor $2 \times 10^{18}$ cells per mole of TdR (Ducklow 2000).

Viral production. Viral production rate was determined by the ${ }^{3} \mathrm{H}$-TdR method with enzyme digestions according to Noble \& Steward (2001) with modifications (Motegi \& Nagata 2007). Triplicate subsamples (7 ml each) were contained in polypropylene tubes (14 ml capacity, BD Falcon), spiked with [methyl- ${ }^{3} \mathrm{H}$ ] TdR (final concentration $10 \mathrm{nM}$ ) and incubated for $1 \mathrm{~h}$ at in situ temperature in the dark. The incubation was terminated by filtering the samples through $0.2 \mu \mathrm{m}$ syringe filters (Acrodisc, Pall). Triplicate filtrates (1.5 ml each) were contained in screw-capped mircocentrifuge tubes ( $2 \mathrm{ml}$ capacity, SSI) and incubated at room temperature for $1 \mathrm{~h}$ with a mixture of nucleases:

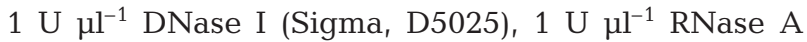

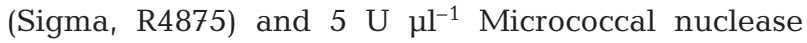
(Worthington, NFCP). After incubation, samples were heated $\left(100^{\circ} \mathrm{C}, 1 \mathrm{~min}\right)$ to denature the enzymes, followed by cooling for $10 \mathrm{~min}$ on ice. To hydrolyze viral capsids and bacteria-derived protein, we treated the samples with Proteinase K $\left(100 \mu \mathrm{g} \mathrm{ml}^{-1}\right.$ final concentration, Sigma, P2308, $37^{\circ} \mathrm{C}$ for $1 \mathrm{~h}$ ). After heating $\left(100^{\circ} \mathrm{C}\right.$ for $1 \mathrm{~min}$ ) and cooling (on ice for $\left.10 \mathrm{~min}\right)$, each sample was spiked with $40 \mu$ l of a carrier solution- 
$50 \mu \mathrm{g} \mathrm{ml}^{-1}$ final concentration each of DNA (Sigma, D4522), RNA (Sigma, R6625) and BSA (Sigma, B4287) - and $80 \mu \mathrm{l}$ of ice-cold $100 \%$ TCA. Precipitates were collected by centrifugation $\left(18000 \times g\right.$ at $4{ }^{\circ} \mathrm{C}$ for $10 \mathrm{~min})$, resuspended in ice-cold 5\% TCA and extracted again by centrifugation. The precipitates were then hydrolyzed with $50 \mu \mathrm{l}$ of $5 \% \mathrm{TCA}$ at $90^{\circ} \mathrm{C}$ for $30 \mathrm{~min}$. After cooling, $1 \mathrm{ml}$ of scintillation cocktail (Ultima Gold, Packard Instruments) was added to each tube for the radioassay (see 'Bacterial production'). The obtained counts were corrected for a blank (40 disintigrations per minute [dpm]). The CVs of triplicate measurements for each bottle and each sampling time were $34 \pm 56 \%( \pm \mathrm{SD}, \mathrm{n}=294)$, excluding 3 samples with erroneously high CVs (>100\%): these data were excluded from the analyses. The ${ }^{3} \mathrm{H}$-TdR incorporation rates were converted to viral production by the conversion factor $6.17 \times 10^{20}$ viruses per mole TdR (Noble \& Steward 2001).

Determination of extracellular leucine aminopeptidase (LAPase) activity. Activity of LAPase was assayed using an analog substrate L-Leucine-7-amido-4-methylcoumarin hydrochloride (Leu-AMC; Sigma, L2145) (Hoppe 1983). The substrate was dissolved in autoclaved and $0.2 \mu \mathrm{m}$-filtered Milli-Q water. Three millilitres were dispensed into acid-washed polymethyl methacrylate cuvettes, spiked with the substrate (final concentration $200 \mu \mathrm{M}$ ) and incubated for 1 to $2 \mathrm{~h}$ at room temperature $\left(20^{\circ} \mathrm{C}\right)$ in the dark. The fluorescence was measured by excitation and emission wavelengths at 380 and $440 \mathrm{~nm}$ with a spectrofluorometer (Jasco, FP-750). LAPase activity was calibrated with 7-Amino4-methylcoumarin (Sigma, A9891). Heat-treated seawater samples were used as blanks.

Abundances of bacteria and viruses. Subsamples for counting bacteria and viruses contained in $2 \mathrm{ml}$ cryovials were fixed with glutaraldehyde (final concentration $0.5 \%$ ) for $30 \mathrm{~min}$ at $4{ }^{\circ} \mathrm{C}$, frozen in liquid nitrogen and stored in a $-80^{\circ} \mathrm{C}$ deep freezer. Before the analysis, samples were defrosted, diluted with $0.2 \mu \mathrm{m}$ filtered TE buffer ( $\mathrm{pH} \mathrm{8),} \mathrm{stained} \mathrm{with} \mathrm{SYBR} \mathrm{Green} \mathrm{I}$ (1:25000 dilution of commercial stock, Molecular probes) for $10 \mathrm{~min}$ at room temperature (for bacteria) or $80^{\circ} \mathrm{C}$ (for viruses) and analyzed with a flow cytometer (FACSCalibur, Becton Dikinson) equipped with a $488 \mathrm{~nm}$ Argon laser according to Brussaard (2004). We lack bacterial and viral abundances data for EXP08, because samples were lost.

Fraction of bacterial production lysed by viruses. The fraction of bacterial production lysed by viruses ( $\mathrm{F}_{\text {lysed }}$ ) was estimated according to the following equation:

$$
\begin{gathered}
\mathrm{F}_{\text {lysed }}=\text { viral production } /(\text { bacterial production } \times \\
\text { burst size })
\end{gathered}
$$

The cumulative values of bacterial and viral production integrated over the time interval between ca. $15 \mathrm{~h}$ (15 to $18 \mathrm{~h}$ depending on experiments) and ca. $60 \mathrm{~h} \mathrm{(54}$ to $68 \mathrm{~h}$ ) were used for this calculation. This time interval was chosen because increases in bacterial abundance and production in response to substrate additions generally occurred after the incubation period of $15 \mathrm{~h}$ (see 'Results'). We assumed that burst size-number of progenies released per each burst event - was 28 (an average value of coastal environments; Parada et al. 2006). Although our estimates of $F_{\text {lysed }}$ have errors associated with assumptions of burst size and conversion factors for determination of bacterial (Ducklow 2000) and viral production (Steward et al. 1992, Helton et al. 2005), we consider that they represent first order estimates of the extent of viral-induced bacterial mortality.

Statistical analyses. Statistical analyses were conducted using SigmaStat (v3.0, SPSS). Mean values among different treatments were compared by 1-way ANOVA followed by post hoc Tukey corrections. If necessary, the data were log-transformed to meet normality and equal variance assumptions. When the normality assumption was not met, a non-parametric test (Kruskal-Wallis 1-way ANOVA on ranks) with Tukey corrections was performed.

\section{RESULTS}

Environmental and microbiological variables of surface waters used in experiments are given in Table 1. Bacterial and viral abundances were on the orders of $1 \times 10^{9}$ cells $\mathrm{l}^{-1}$ and $2 \times 10^{10}$ viruses $\mathrm{l}^{-1}$, respectively, yielding virus to bacterial abundance ratios of 17 to 30 .

\section{Changes in bacterial and viral variables during incubation}

In EXP06, bacterial abundances in glucose and protein addition treatments during the later period of incubation ( $>20 \mathrm{~h}$ ) were much higher than those in the non-addition control (Fig. 1A). Effects of substrate addition to viral abundance were not as pronounced as those for bacterial abundance (Fig. 1B). Bacterial production displayed a substantial (100-fold) increase after $15 \mathrm{~h}$ incubation in the glucose addition treatment, which was accompanied by a peak in viral production at $21 \mathrm{~h}$ (Figs. 1C, D). Protein addition also resulted in the enhancement of bacterial production (Fig. 1C), although there was no concomitant increase in viral production (Fig. 1D).

In EXP07, bacterial abundance differed among treatments during the later period ( $>24 \mathrm{~h}$ ) of incubation, with higher values in protein and glucose addi- 
Table 1. Temperature, salinity and microbiological variables of the Otsuchi Bay surface waters used for the experiments. Bacterial and viral variables were determined for prefiltered sample waters at the beginning of the experiments (see 'Materials and methods'). EXP06: 15 to 17 May 2006; EXP07: 16 to 18 May 2007; EXP08: 23 to 26 May 2008. Values are means \pm SD (n = 3). N.D.: no data available

\begin{tabular}{|c|c|c|c|c|c|c|c|}
\hline Expt & $\begin{array}{c}\text { Temp. } \\
\left({ }^{\circ} \mathrm{C}\right)\end{array}$ & Salinity & $\begin{array}{c}\text { Bacterial } \\
\text { abundance } \\
\left(\times 10^{8} \text { cells } l^{-1}\right)\end{array}$ & $\begin{array}{c}\text { Viral } \\
\text { abundance } \\
\left(\times 10^{10} \text { viruses } 1^{-1}\right)\end{array}$ & $\begin{array}{c}\text { Virus:bacteria } \\
\text { ratio }\end{array}$ & $\begin{array}{c}\text { Bacterial } \\
\text { production } \\
\left(\times 10^{7} \text { cells } \mathrm{l}^{-1} \mathrm{~h}^{-1}\right)\end{array}$ & $\begin{array}{c}\text { Viral } \\
\text { production } \\
\left(\times 10^{7} \text { viruses } \mathrm{l}^{-1} \mathrm{~h}^{-1}\right)\end{array}$ \\
\hline EXP06 & 9.0 & 33.8 & $8.8 \pm 0.2$ & $2.6 \pm 0.1$ & 30 & $2.8 \pm 0.3$ & $20 \pm 10$ \\
\hline EXP07 & 11.4 & 31.0 & $9.8 \pm 0.5$ & $1.7 \pm 0.3$ & 17 & $5.4 \pm 0.5$ & $90 \pm 20$ \\
\hline EXP08 & 11.0 & 34.0 & N.D. & N.D. & N.D. & $6.1 \pm 0.5$ & $80 \pm 20$ \\
\hline
\end{tabular}


tion treatments (Fig. 2A). Substrate additions resulted in enhanced bacterial production, with patterns in time-course changes similar to those in EXP06 (Fig. 2C). In contrast, viral abundance and production did not differ significantly ( $p>0.05$ ) among different treatments (Fig. 2B, D).

In EXP08, protein addition resulted in enhanced bacterial production relative to the non-addition control (Fig. 3A). Amino acid addition also enhanced bacterial production during the later period of incubation $(>40 \mathrm{~h}$ ) (Fig. 3A). In contrast, viral production did not differ significantly ( $p$ > 0.05) among different treatments (Fig. 3B).

\section{LAPase activity}

In all the experiments, LAPase activity displayed a substantial increase after the incubation period of 15 to $20 \mathrm{~h}$ in the protein addition treatment (Fig. 4). The maximum levels of activity in the protein addition treatment were achieved at the later period of incubation, which were 27 - to 50 -fold higher than the initial values. The enhancement of LAPase activity was less pronounced in the glucose or amino acid addition treatments: the maximum values were only 2- to 10 fold higher than the initial values. In the non-addition control, LAPase activity was low and varied little during the incubation period.

\section{Fraction of bacterial production lysed by viruses}

The estimates of $F_{\text {lysed }}$ displayed a systematic variation among treatments (Fig. 5). In all experiments,

Fig. 1. Time-course changes in (A) bacterial and (B) viral abundance and $(\mathrm{C})$ bacterial and (D) viral production in the non-addition control (control, @), monomer addition treatment (glucose, $\square$ ) and protein addition treatment (protein, $\mathbf{\nabla}$ ) in EXP06. Error bars are SD for triplicate bottles $(n=3)$. The cause of abrupt change in bacterial abundance between 36 and $54 \mathrm{~h}$ was unclear 



Fig. 2. Time-course changes in (A) bacterial and (B) viral abundance and (C) bacterial and (D) viral production in the non-addition control (control, @), monomer addition treatment (glucose, $\square$ ) and protein addition treatment (protein, $\mathbf{\nabla}$ ) in EXP07. Error bars are SD for triplicate bottles $(n=3)$

$\mathrm{F}_{\text {lysed }}$ was highest in the non-addition control, followed by the monomer addition treatment, and lowest in the protein addition treatment. In EXP06 and EXP08, the differences in $\mathrm{F}_{\text {lysed }}$ among treatments were significant (ANOVA, $\mathrm{p}<0.05$ ). In EXP07, $\mathrm{F}_{\text {lysed }}$ in the non-addition control was significantly (Kruskal-Wallis ANOVA on


Fig. 3. Time-course changes in (A) bacterial and (B) viral production in the non-addition control (control, $\bullet$ ), monomer addition treatment (amino acids, $\diamond$ ) and protein addition treatment (protein, $\boldsymbol{\nabla}$ ) in EXP08. Error bars are SD for triplicate bottles $(n=3)$

ranks; $\mathrm{p}<0.05$ ) higher than the corresponding values in the protein addition treatment, whereas the difference between the protein addition and monomer addition treatments was not significant $(p>0.05)$.

\section{DISCUSSION}

We found that additions of monomeric and polymeric substrates enhanced bacterial production, consistent with results obtained by previous studies (Kirchman 1990, Church et al. 2000). However, the extent and timing of the enhancement differed among experiments and with the type of organic substrate added. A substantial, albeit transient, increase in bacterial production in response to glucose addition was accompanied by a pulsed increase in viral production in EXP06, suggesting that viral production was enhanced with increasing productivity of host community, as has been reported previously (Williamson \& Paul 2004, Motegi \& Nagata 2007, Motegi et al. 2009). However, in other experiments, we failed to detect an enhancement of viral production in response to the addition of glucose (EXP07) or amino acids (EXP08). Similarly, responses of viral variables to the protein addition were less evident, with little enhancement of viral production and abundance relative to the corresponding values in the 

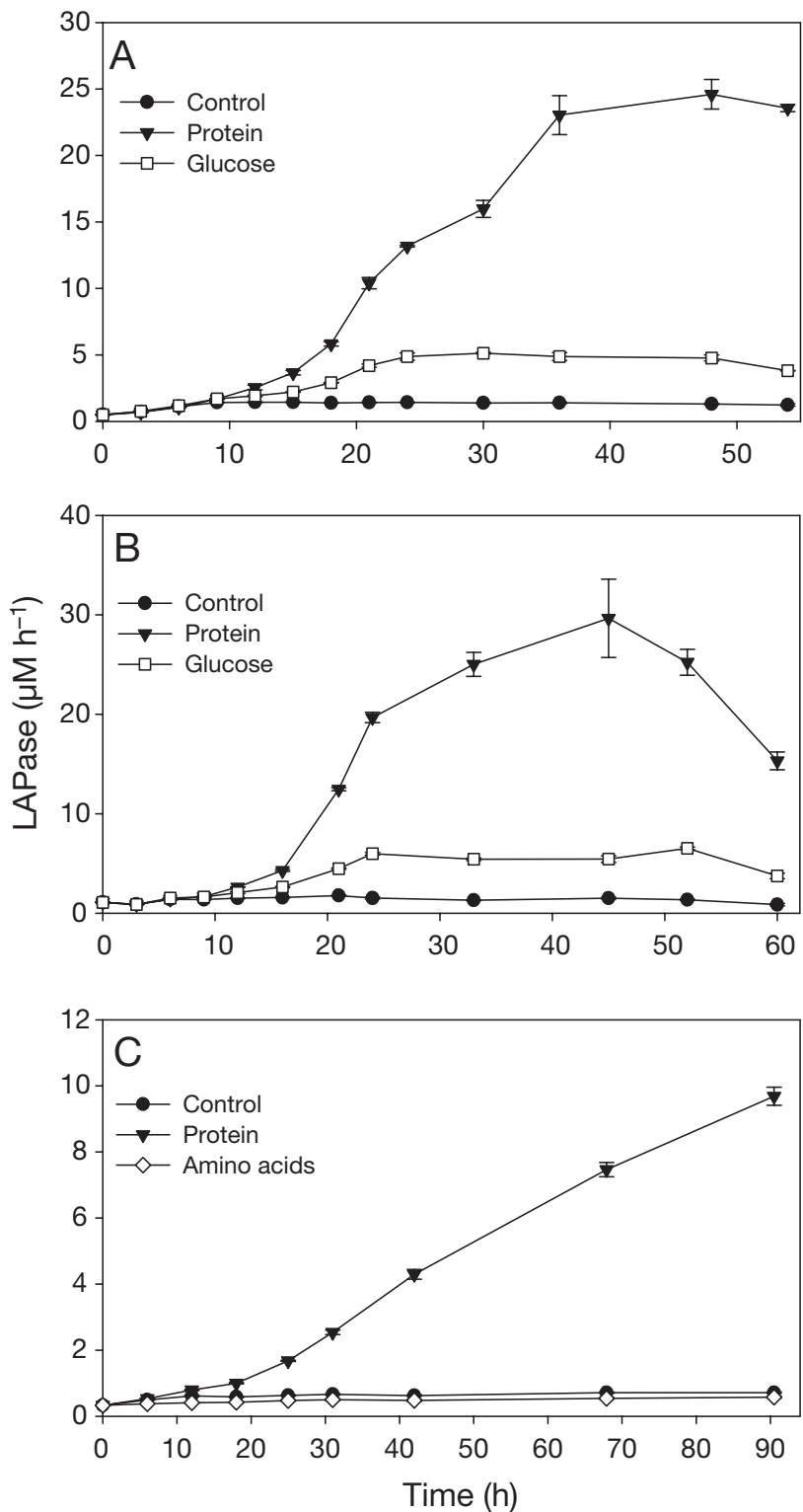

Fig. 4. Time-course changes in the leucine aminopeptidase (LAPase) activity $\left(\mathrm{MM} \mathrm{h}^{-1}\right)$ in the non-addition control (control,

๑), monomer addition treatment (glucose, $\square$, or amino acids, $\diamond)$ and protein addition treatment (protein, $\nabla$ ) in (A) EXP06,

(B) EXP07 and (C) EXP08. Error bars are SD for triplicate bottles $(n=3)$

non-addition control. Taken together, our results indicate that bacterial communities developed in substrate-enriched cultures were less subject to viral lysis than bacterial communities grown in the non-addition control.

There were systematic variations in $\mathrm{F}_{\text {lysed }}$ across different treatments; the average values of $F_{\text {lysed }}$ in the non-addition control were much higher than those in the monomer and protein addition treatments. The highest value of $\mathrm{F}_{\text {lysed }}$ determined in the non-addition control of EXP07 (1.04) indicated that bacterial growth
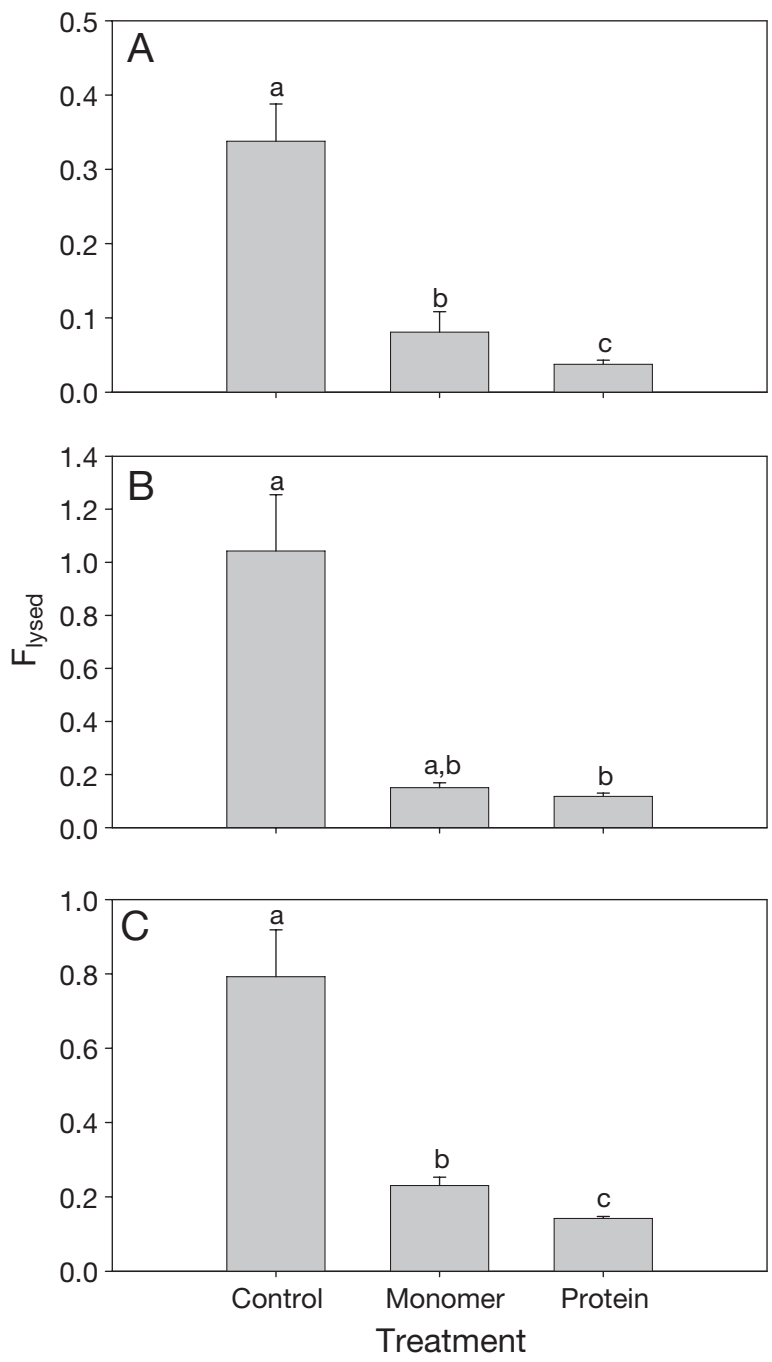

Fig. 5. Cumulative values of the fraction of bacterial production lysed by viruses $\left(\mathrm{F}_{\text {lysed }}\right)$ in (A) EXP06, (B) EXP07 and (C) EXP08. Error bars are SD for triplicate bottles $(n=3)$. Different letters identify the treatments for which the mean values differed significantly $(p<0.05)$. For EXP06 and EXP08, multiple comparisons by 1-way ANOVA with Tukey corrections were conducted (data were log-transformed). For EXP07, Kruskal-Wallis ANOVA on ranks with Tukey corrections was conducted because the normality assumption was not met

was balanced by viral-induced mortality and was consistent with minimal changes in bacterial abundance over the period of incubation in that culture. In contrast, estimates of $F_{\text {lysed }}$ were generally low $(<0.23)$ in the monomer and protein addition treatments, indicating that viral lytic pressures posed on bacterial communities grown on substrate-rich seawater cultures were low.

Several factors could be related to the reduction in $\mathrm{F}_{\text {lysed }}$ in seawater cultures amended with organic substrate. Changes in bacterial community composition in response to the addition of organic substrates have been documented (Pinhassi et al. 1999, Castle \& Kirch- 
man 2004) which appear to be related to group-specific utilization of DOM. Cottrell \& Kirchman (2000) found that the capacity to assimilate proteins (polymers) and amino acids (monomers) differed among bacterial major groups: Cytophaga-like bacteria and Alphaproteobacteria dominated in the use of proteins and amino acids, respectively. Consequently, bacterial community compositions might have changed with time differently among different treatments in our experiments. We note that bacterial and viral communities developed in seawater cultures do not necessarily represent those which might develop in natural systems. In seawater cultures without grazers (as was the case in our experiments), the fast-growing 'weedy' bacteria (e.g. Vibrio) could grow explosively upon substrate additions, more quickly than the viruses that may infect them. This growth enhancement of laboratory weeds in seawater cultures might partly explain differential responses of bacteria and viruses to substrate additions. However, this situation could still reflect realistic conditions, when there is a burst of organic matter (e.g. during a sudden bloom).

Bacterial communities developed in organic-rich seawaters might be more resistant to viral attacks than those grown in the non-addition control. Bacterial traits that are responsible for antiviral defense include reduction in numbers or masking of receptors to minimize viral adsorption (Lenski 1988, Forde \& Fitzgerald 1999). Post-infection defensive mechanisms (e.g. destruction of viral genome by nucleases) may also operate to inhibit viral proliferation (Lenski 1988). Tradeoffs likely exist between traits of antiviral defense and resource competition (Thingstad et al. 2005). Therefore, it follows that organic enrichment may alleviate resource competition and allow bacterial communities to pay the 'costs' involved in increasing antiviral defenses.

Interestingly, we found that average estimates of $\mathrm{F}_{\text {lysed }}$ in the protein addition treatment were significantly lower than the corresponding values in the monomer addition treatment in 2 out of 3 experiments. High protease activities in the protein addition treatment might account for this result. To test this hypothesis, we examined relationships between $F_{\text {lysed }}$ and LAPase activity using all data obtained from the 3 experiments. The results showed that $F_{l y s e d}$ tended to decrease with increasing LAPase activity $(\mathrm{r}=-0.76$, Fig. 6), supporting the notion that proteases play a role in alleviation of viral lytic pressures. Some studies have suggested that extracellular proteases produced by bacteria are a major factor responsible for the loss of viral infectivity in aquatic systems (Ward et al. 1986, Noble \& Fuhrman 1997). The mechanism involved may be the hydrolytic destruction or modification of viral capsids (Ward et al. 1986, Nuanualsuwan \& Cliver



Fig. 6. Relationship between time-weighted average leucine aminopeptidase (LAPase) activity $\left(\mu \mathrm{M} \mathrm{h}^{-1}\right)$ and the fraction of bacterial production lysed by viruses $\left(\mathrm{F}_{\text {lysed }}\right)$. Note the log scale on both axes. Each symbol represents the data obtained for an individual bottle: non-addition control (control, ๑), monomer addition treatment (glucose, $\square$, or amino acids, $\diamond$ ) and protein addition treatment (protein, $\boldsymbol{\nabla}$ ). The linear regression equation is: $\log \mathrm{F}_{\text {lysed }}=-0.60 \times \log L A P a s e-0.41$; $\mathrm{n}=27, \mathrm{r}^{2}=0.57, \mathrm{p}<0.001$

2003). Viral capsids play critical roles in protection of viral genomes, attachment to host receptors and injection of viral nucleic acids to the host cells (Fujisawa \& Morita 1997, Nuanualsuwan \& Cliver 2003); even partial cleavage of viral capsids by proteases can result in substantial loss of infectivity (Ward et al. 1986). Thus bacterial extracellular proteases synthesized for exploitation of protein resources (Nagata 2008) might also reduce viral-induced mortality of bacteria via destruction of viral capsids.

Our experiments using bottle-contained seawater cultures did not fully capture the complexity of organic matter-bacteria-virus interactions in seawater. Elimination of large particles by prefiltration can alter organic matter supply regimes and viral-bacteria interactions (Weinbauer et al. 2009, this Special Issue). Prefiltration also eliminated protist grazers, which may exert a large influence on bacterial and viral dynamics in a complex manner (Zhang et al. 2007). As already mentioned, the elimination of grazers could allow 'weedy' or 'opportunistic' bacteria to grow rapidly at a pace exceeding that of viruses, which might explain our observation that viral abundance in general did not respond strongly to the treatments, while bacterial abundance did. Further studies are required to clarify role of grazers in the control of bacteria-virus dynamics under the conditions of variable substrate supply regimes. Despite the limitations, our results corroborate the previous assertion that enhanced bacterial production due to nutrient enrichment does not always result in a proportional increase in viral production in 
marine waters (Motegi \& Nagata 2007). Rather, viral response is largely suppressed with increasing bacterial production, one possible explanation being the expression of antiphage traits of bacteria under nutrient-rich conditions. The potential involvement of extracellular proteases in the reduction of viralinduced mortality of bacteria merits further investigation.

Acknowledgements. This paper is dedicated to F. Rassoulzadegan, celebrating his outstanding career and achievements in aquatic microbial ecology. This study was supported by the collaborative research program of the International Coastal Research Center (ICRC) of the Ocean Research Institute. We thank the staff of ICRC, especially H. Fukuda, for logistical support. T. Yokokawa and C. Kim assisted in sampling. Financial support was provided by the 21st Century Center of Excellence program (Kyoto University) and by Japan Society for the Promotion of Science grants (nos. 18631007 and 20310010) awarded to T.N.

\section{LITERATURE CITED}

Breitbart M, Middelboe M, Rohwer F (2008) Marine viruses: community dynamics, diversity and impact on microbial processes. In: Kirchman DL (ed) Microbial ecology of the oceans, 2nd edn. John Wiley \& Sons, New York, p 443-379

Brussaard CPD (2004) Optimization of procedures for counting viruses by flow cytometry. Appl Environ Microbiol 70:1506-1513

Castle D, Kirchman DL (2004) Composition of estuarine bacterial communities assessed by denaturing gradient gel electrophoresis and fluorescence in situ hybridization. Limnol Oceanogr Methods 2:303-314

Church MJ, Hutchins DA, Ducklow HW (2000) Limitation of bacterial growth by dissolved organic matter and iron in the Southern Ocean. Appl Environ Microbiol 66:455-466

Cottrell MT, Kirchman DL (2000) Natural assemblages of marine proteobacteria and members of the CytophagaFlavobacter cluster consuming low- and high-molecularweight dissolved organic matter. Appl Environ Microbiol 66:1692-1697

Ducklow H (2000) Bacterial production and biomass in the oceans. In: Kirchman DL (ed) Microbial ecology of the oceans. John Wiley \& Sons, New York, p 85-120

Forde A, Fitzgerald GF (1999) Bacteriophage defense systems in lactic acid bacteria. Antonie Leeuwenhoek 76:89-113

Fujisawa H, Morita M (1997) Phage DNA packaging. Genes Cells 2:537-545

Fukuda H, Ogawa H, Sohrin R, Yamasaki A, Koike I (2007) Sources of dissolved organic carbon and nitrogen in Otsuchi Bay on the Sanriku ria coast of Japan in the spring. Coast Mar Sci 31:19-29

> Helton RR, Cottrell MT, Kirchman DL, Wommack KE (2005) Evaluation of incubation-based methods for estimating virioplankton production in estuaries. Aquat Microb Ecol 41:209-219

Hoppe HG (1983) Significance of exoenzymatic activities in the ecology of brackish water: measurements by means of methylumbelliferyl-substrates. Mar Ecol Prog Ser 11: 299-308

Kirchman DL (1990) Limitation of bacterial growth by dis- solved organic matter in the subarctic Pacific. Mar Ecol Prog Ser 62:47-54

Kirchman DL (2001) Measuring of bacterial biomass production and growth rates from leucine incorporation in natural aquatic environments. In: Paul JH (ed) Methods in microbiology, Vol 30. Academic Press, San Diego, CA, p 227-237

Lenski RE (1988) Dynamics of interactions between bacteria and virulent bacteriophage. Adv Microb Ecol 10:1-44

Middelboe M (2000) Bacterial growth rate and marine virus-host dynamics. Microb Ecol 40:114-124

Motegi C, Nagata T (2007) Enhancement of viral production by addition of nitrogen or nitrogen plus carbon in subtropical surface waters of the South Pacific. Aquat Microb Ecol $48: 27-34$

Motegi C, Nagata T, Miki T, Weinbauer MG, Legendre L, Rassoulzadegan F (2009) Viral control of bacterial growth efficiency in marine pelagic environments. Limnol Oceanogr 54:1901-1910

Nagata T (2008) Organic matter-bacteria interactions in seawater. In: Kirchman DL (ed) Microbial ecology of the oceans, 2nd edn. John Wiley \& Sons, New York, p 207-241

> Noble RT, Fuhrman JA (1997) Virus decay and its causes in coastal waters. Appl Environ Microbiol 63:77-83

Noble RT, Steward GF (2001) Estimating viral proliferation in aquatic samples. In: Paul JH (ed) Methods in microbiology, Vol 30. Academic Press, San Diego, CA, p 67-84

Nuanualsuwan S, Cliver DO (2003) Capsid functions of inactivated human picornaviruses and feline calicivirus. Appl Environ Microbiol 69:350-357

Parada V, Herndl GJ, Weinbauer MG (2006) Viral burst size of heterotrophic prokaryotes in aquatic systems. J Mar Biol Assoc UK 86:613-621

Pinhassi J, Azam F, Hemphala J, Long RA, Martinez J, Zweifel UL, Hagstrom A (1999) Coupling between bacterioplankton species composition, population dynamics, and organic matter degradation. Aquat Microb Ecol 17: $13-26$

Steward GF, Wikner J, Smith DC, Cochlan WP, Azam F (1992) Estimation of virus production in the sea: I. Method development. Mar Microb Food Webs 6:57-78

Thingstad TF, Øvreås L, Egge JK, Løvdal T, Heldal M (2005) Use of non-limiting substrates to increase size; a generic strategy to simultaneously optimize uptake and minimize predation in pelagic osmotrophs? Ecol Lett 8:675-682

Tuomi P, Fagerbakke KM, Bratbak G, Heldal M (1995) Nutritional enrichment of a microbial community: the effects on activity, elemental composition, community structure and virus production. FEMS Microbiol Ecol 16:123-134

> Ward RL, Knowlton DR, Winston PE (1986) Mechanism of inactivation of enteric viruses in fresh water. Appl Environ Microbiol 52:450-459

Weinbauer MG (2004) Ecology of prokaryotic viruses. FEMS Microbiol Rev 28:127-181

Weinbauer MG, Bettarel Y, Cattaneo R, Luef B and others (2009) Viral ecology of organic and inorganic particles in aquatic systems: avenues for further research. Aquat Microb Ecol 57:321-341

Williamson SJ, Paul JH (2004) Nutrient stimulation of lytic phage production in bacterial populations of the Gulf of Mexico. Aquat Microb Ecol 36:9-17

Zhang R, Weinbauer MG, Qian PY (2007) Viruses and flagellates sustain apparent richness and reduce biomass accumulation of bacterioplankton in coastal marine waters. Environ Microbiol 9:3008-3018 